УДК 615.322:582.287.237

\title{
ИССЛЕДОВАНИЕ МЕЛАНИНА ЧАГИ. І. ЛИПОФИЛЬНЫЕ ВЕЩЕСТВА МЕЛАНИНА ЧАГИ
}

\author{
(C) С.А. Никитина , В.Р. Хабибрахманова, М.А. Сысоева
}

\author{
Казанский национальный исследовательский технологический университет, \\ ул. К. Маркса, 68, Казань, 420015 (Россия), e-mail: semicvetik-86@bk.ru
}

\begin{abstract}
Проведен анализ количественного и качественного состава липофильных веществ, экстрагируемых петролейным эфиром из меланина чаги. Показано наличие моно-, ди- и триглицеридов, О-диалкиловых эфиров глицерина, высших жирных кислот и алифатических спиртов, углеводородов и восков, стеринов и их эфиров. Впервые определено, что липофильные вещества находятся в меланине чаги в связанном состоянии, и для их разделения была применена колоночная хроматография. Установлено, что до $43 \%$ от липофильных веществ меланина чаги представлено углеводородами и восками и до $11 \%$ - стериновыми соединениями.

Ключевые слова: чага, водное извлечение, меланин, липофильные вещества, стериновые соединения.

Работа выполнена при финансовой поддержке Министерства образования и науки Российской Федерачии в рамках целевой программы «Исследования и разработки по приоритетным направлениям развития научно-технического комплекса России на 2007-2013 г2.» по Госконтракту №01201252915 от 28.02.2012, а также при финансовой поддержке Фонда содействия развитию малых форм предприятий в научно-технической сфере по программе «У.М.Н.И.К.».
\end{abstract}

\section{Введение}

В настоящее время высшие грибы являются перспективным природным объектом для разработки на их основе лекарственных препаратов, биологически активных добавок и косметических средств. Актуальность исследования высших грибов обусловлена содержанием в них разнообразных биологически активных веществ, продуцируемых и накапливаемых ими в процессе своей жизнедеятельности.

Значительное количество меланина по сравнению с другими базидиомицетами накапливает березовый гриб чага, который является лекарственным сырьем, включенным в фармакопею [1]. Стандартизируют сырье именно по содержанию в нем меланина - основного действующего компонента чаги.

Особый интерес представляют вещества, входящие в состав меланина, которые могут обеспечивать его высокую биологическую активность. Известно, что меланин чаги состоит из аморфных частиц, которые организованы из агрегатов и субагрегатов различной формы и размеров. В формировании этих частиц участвуют продукты ферментативного распада древесины и древесной коры, включающие полимерные (лигнин, полифенолы, полисахариды, белки) и мономерные (простые фенолы, фенолкарбоновые кислоты и зольные вещества) соединения [2-4].

Никитина Светлана Александровна - аспирант кафедры пищевой биотехнологии, e-mail: semicvetik-86@bk.ru Хабибрахманова Венера Равилевна - кандидат химических наук, доцент кафедры пищевой биотехнологии, e-mail: venha@rambler.ru Сысоева Мария Александровна - доктор химических наук, профессор, заведующая кафедрой пищевой биотехнологии, e-mail: oxygen1130@mail.ru
В меланине чаги было показано наличие липофильных веществ, включающих высшие жирные кислоты и их эфиры, углеводороды, высшие алифатические спирты и альдегиды [5, 6]. Данные соединения были обнаружены в гидролизате, полученном при химическом гидролизе меланина в «жестких» условиях, что может приводить к изменению химической структуры биологически активных веществ.

\footnotetext{
* Автор, с которым следует вести переписку.
} 
Использование более «мягких» способов, в частности экстракция водных извлечений чаги различными растворителями: петролейным эфиром, этилацетатом, хлороформом и хлороформ-этанольной смесью, позволила расширить спектр обнаруженных в чаге липофильных веществ. Во всех полученных органических экстрактах показано наличие моно-, ди- и триацилглицеридов, алифатических спиртов и альдегидов, стеринов и их эфиров, углеводородов, восков, витаминов Е и К, кофермента Q, высших жирных кислот [7-9].

Водное извлечение чаги представляет собой коллоидную систему, дисперсной фазой которой является меланин. При этом липофильные вещества водного извлечения чаги находятся в его составе в связанном с ним состоянии [7].

Большинство выделенных из чаги липофильных веществ обладают биологической активностью [10, 11]. В частности, к ним относятся стериновые соединения, для которых доказаны высокие противоопухолевые, имунномодулирующие и противовоспалительные свойства [12-14]. Поскольку перспективен поиск возможности получения лекарственных препаратов на основе меланина чаги, то актуально исследование качественного и количественного состава липофильных веществ, входящих в его состав. Полученные результаты позволят расширить спектр биологически активных веществ, входящих в состав меланина чаги, а также разработать методику стандартизации лекарственных препаратов и биологически активных добавок, выпускаемых на основе меланина чаги.

Цель исследования - анализ количественного и качественного состава липофильных веществ меланина чаги.

\section{Экспериментальная часть}

Для исследования использовали сырье чаги, приобретенное в аптечной сети: сырье 1 - ЗАО «Фирма Здоровье» партия 100808, сырье 2 - ОАО «Красногорсклексредства» партия 40707, сырье 3 - ОАО «Красногорсклексредства» партия 61208 и сырье 4 - ОАО «Красногорсклексредства» партия 10210.

Получение водных извлечений чаги и выделение из них меланина проводили согласно методикам $[15,16]$. Меланин чаги экстрагировали петролейным эфиром согласно [17]. В полученных экстрактах определяли содержание сухих веществ [18], стеринов и их эфиров [19]. Качественный состав липофильных веществ экстрактов анализировали методом ТCX на пластинках «Sorbfil» в системах растворителей петролейный эфир - диэтиловый эфир - уксусная кислота (90:10:1) [20], толуол - муравьиная кислота - этилацетат $(5: 1: 4)$ [21]. В качестве веществ-стандартов использовали миристиновую кислоту, ланостерол (№S446793-1EA Sigma-Aldrich) и сквален (№S3626-10ML Sigma-Aldrich).

Экстракты меланинов чаги разделяли с помощью колоночной хроматографии. Пробоподготовку вели по следующей схеме: из экстракта полностью удаляли петролейный эфир путем отгонки при пониженном давлении, полученный сухой остаток растворяли в этаноле, при этом образовывался осадок, содержащий до 3,5\% от суммы экстрактивных веществ. Выпавший осадок отделяли из этанольного раствора липофильных веществ и высушивали. Полученный этанольный раствор экстрактивных веществ вносили в ко-

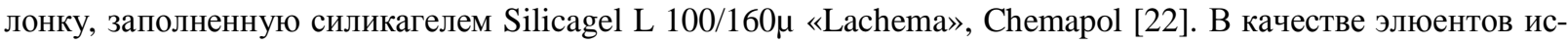
пользовали гексан, смесь гексана с петролейным эфиром в соотношениях $99: 1,95: 5,92: 8,85: 15$, затем петролейный эфир и гексан с этилацетатом в соотношениях $10: 1,5: 1,1: 1,1: 5,1: 10$. В полученных пробах определяли содержание веществ и анализировали их качественный состав методом ТCX $[18,20]$. Газовую хроматографию исследуемых образцов проводили на хроматографе «Кристалл $2000 \mathrm{M»} \mathrm{в} \mathrm{режиме}$ программирования температуры от 100 до $300{ }^{\circ} \mathrm{C}$. В диапазоне температур от 100 до $150{ }^{\circ} \mathrm{C}$ изменение температуры проводили со скоростью $-10{ }^{\circ} \mathrm{C} /$ мин и в диапазоне от 150 до $300{ }^{\circ} \mathrm{C}-3{ }^{\circ} \mathrm{C} /$ мин. В качестве газа-носителя использовался водород.

Обработку экспериментальных данных проводили с использованием программного пакета «Statistica 6.0».

\section{Обсуждение результатов}

Исчерпывающая экстракция меланина чаги петролейным эфиром проведена по разработанной методике [17]. В полученных экстрактах меланина чаги из разных партий сырья определено содержание липофильных и стериновых веществ (табл. 1).

Показано, что содержание липофильных и стериновых веществ водного извлечения и меланина чаги различается в зависимости от партии сырья, взятой для исследования. В целом, из водного извлечения чаги по сравнению с меланином экстрагируется в 12-14 раз больше липофильных веществ. Это, возможно, связано с тем, что при перемешивании петролейный эфир за счет гидродинамического удара глубже проникает в частицу меланина, находящегося в водном извлечении чаги, и позволяет извлечь из нее большее количество липофильных веществ. 
Таблица 1. Содержание липофильных и стериновых веществ в экстрактах водного извлечения и меланина чаги

\begin{tabular}{c|c|c|c|c}
\hline \multirow{2}{*}{ Сырье } & \multicolumn{2}{|c|}{ Липофильные вещества } & \multicolumn{2}{c}{ Стериновые вещества } \\
\cline { 2 - 4 } & меланина, \%** & водного извлечения*,\%*** & меланина, \%***** & водного извлечения*, \%**** \\
\hline 1 & $0,65 \pm 0,03$ & $0,40 \pm 0,02$ & $2,17 \pm 0,51$ & $44,19 \pm 0,02$ \\
2 & $0,14 \pm 0,02$ & $1,67 \pm 0,05$ & $2,89 \pm 1,17$ & $1,37 \pm 0,05$ \\
3 & $0,71 \pm 0,04$ & $\ldots$ & $3,53 \pm 0,83$ & $\ldots$ \\
4 & $0,22 \pm 0,04$ & $3,07 \pm 0,10$ & $7,98 \pm 1,46$ & $1,32 \pm 0,10$ \\
\hline
\end{tabular}

Примечание: * ссылка [9]; ** в \% от сухих веществ меланина чаги; *** в \% от сухих веществ водного извлечения чаги; **** в \% от суммы липофильных веществ.

Кроме того, следует отметить, что анализируемый меланин представляет только часть дисперсной фазы водного извлечения чаги. Другая фракция дисперсной фазы после выделения анализируемого меланина остается в фильтрате [23].

Согласно данным, приведенным в таблице 1, стериновые соединения накапливаются грибом чага в небольшом количестве - от 1 до $8 \%$ от суммы извлекаемых липофильных веществ. Причем петролейным эфиром из сырья можно извлечь в среднем 0,50\% липофильных веществ, из них от 8 до $13 \%$ представлено стериновыми соединениями [24]. Это свидетельствует о том, что основная часть липофильных веществ гриба переходит в водное извлечение. В случае сырья 1 стериновые соединения присутствуют в нем в количестве, которое в 8 раз превышает содержание этих веществ в других партиях сырья. Это может быть связано с особенностью метаболизма гриба, например, при росте в неблагоприятных условиях, что приводит к накоплению стериновых соединений в таких больших количествах.

Проведен качественный анализ липофильных веществ в экстрактах меланинов чаги с помощью TCX. В них показано наличие моно-, ди- и триглицеридов, О-диалкиловых эфиров глицерина, высших жирных кислот и алифатических спиртов, углеводородов и восков, стеринов и их эфиров. В экстракте меланина из сырья 4 дополнительно обнаруживаются высшие алифатические альдегиды. Таким образом, применение петролейного эфира для выделения липофильных веществ из меланина чаги позволило обнаружить все липофильные вещества, найденные ранее в водных извлечениях чаги, кроме алкен-1илдиглицеридов, витамина Е и кофермента Q [9].

Поскольку в петролейном экстракте могут содержаться ассоциаты, включающие различные по природе липофильные вещества, для их разрушения и уточнения количественного и качественного состава этих веществ была применена колоночная хроматография. Для исследования были выбраны два экстракта: полученный при обработке меланина из сырья 3 с наибольшим содержанием экстрактивных веществ, и полученный при обработке меланина из сырья 4 с наибольшим содержанием стериновых соединений (табл. 1). Из петролейного экстракта был удален растворитель, а сухой остаток растворен в этаноле. В результате проведения колоночной хроматографии этанольного раствора были получены 16 проб. В каждой пробе определен количественный и качественный состав соединений (табл. 2).

В исследованных меланинах чаги преобладают углеводороды и воски. Согласно полученным данным, чага, сырье 3 и 4, сильно отличаются происходившими в этих грибах процессами метаболизма. В меланине чаги (сырье 4) снижено количество веществ, отвечающих за энергетические запасы клетки, ацилглицеридов и высших жирных кислот.

Суммарно при элюировании липофильных веществ, входящих в состав этанольного раствора, удалось разделить лишь до 56\% от их количества. Остальные неразделенные вещества экстрактов наблюдались в колонке в виде окрашенных зон - желтой, оранжевой и розовой в верхнем слое силикагеля. Для разделения веществ, находящихся в окрашенных зонах, и их идентификации была подобрана система элюентов, представляющая собой смесь гексана с этилацетатом и затем этилацетат. Получены еще 15 проб (табл. 3).

Таблица 2. Состав липофильных веществ этанольных растворов меланинов чаги

\begin{tabular}{c|c|c|c}
\hline \multirow{2}{*}{$№$} & Содержание веществ \%* & \multirow{2}{*}{ Обнаруженные вещества } \\
\cline { 2 - 3 } пробы & сырье 3 & сырье 4 & Углеводороды, воски \\
\hline 1 & 40,07 & 43,19 & Эфиры стеринов \\
$2-4$ & 4,00 & 0,71 & Триацилглицериды \\
$5-8$ & 2,20 & следы \\
$9-10$ & 7,87 & 0,61 & Жирные кислоты, алифатические спирты \\
$11-13$ & 1,61 & 0,10 & Диацилглицериды \\
$14-16$ & 0,53 & 0,10 & Моноацилглицериды \\
\hline \multicolumn{2}{l}{ Итого: } & 44,71 & \\
\multicolumn{2}{l}{ Примечание. * от сухих веществ экстракта. }
\end{tabular}

Примечание. * - от сухих веществ экстракта. 
Как показано в таблице 3, применение такого разделения окрашенных зон позволило показать присутствие в них еще до $9 \%$ стериновых соединений.

Особенности строения стериновых соединений связаны с их способностью образовывать комплексы с различными соединениями - фенолами, спиртами, кислотами и их производными, гетероциклическими соединениями [25, 26]. Этим, вероятно, объясняется то, что распад комплексов и высвобождение стериновых соединений происходит только при применении более полярного растворителя - этилацетата. Согласно данным, приведенным в таблице 4, судя по специфической окраске пятен, в анализируемых объектах присутствуют терпены различного строения. Кроме того, сравнением значений $\mathrm{R}_{\mathrm{f}}$ с метчиком и данными, приведенными в литературе [21], зафиксированы ланостерол и его производные - инотодиол, траметеноловая кислота.

Анализ проб 22-23 с помощью ГЖХ проведен с применением ланостерола в качестве внутреннего стандарта. Согласно полученным данным в их составе показана многокомпонентная смесь. Суммарно в пробах обнаружено более 30 соединений в отличие от результатов тонкослойной хроматографии, с помощью которой обнаружено 9 соединений. Проба 22 кроме ланостерола представлена в основном алифатическими спиртами, а проба 23 преимущественно содержит производные ланостерола.

Таблица 3. Состав липофильных веществ этанольных растворов при вторичном разделении

\begin{tabular}{c|c|c|c}
\hline \multirow{2}{*}{ № пробы } & \multicolumn{2}{|c|}{ Содержание веществ, \%* } & Характеристика проб \\
\cline { 2 - 3 } & сырье 3 & сырье 4 & Моноалкиловые эфиры глицерина \\
\hline $17-19$ & 0,54 & 0,10 & Вещества, формирующие желтую зону, - желтое масло \\
20,21 & 19,92 & 16,27 & Алифатические спирты, стерины \\
22,23 & 7,33 & 9,10 & Не идентифицированы \\
$24-28$ & 1,49 & 4,10 & Вещества, формирующие розовую зону \\
29 & 0,72 & 1,43 & \\
\hline Итого: & 30,00 & 31,00 & \\
\hline
\end{tabular}

Примечание. * - от сухих веществ экстракта.

Таблица 4. Хроматографический анализ стериновых соединений (пробы 22-23)

\begin{tabular}{|c|c|c|c|}
\hline Проба & Коэффициент распределения $\left(\mathrm{R}_{\mathrm{f}}\right)$ & Окраска пятна & Идентификация \\
\hline \multicolumn{4}{|c|}{ петролейный эфир - диэтиловый эфир - уксусная кислота $(90: 10: 1)^{*}$} \\
\hline \multirow{5}{*}{22} & 0,16 & фиолетовое & \multirow{5}{*}{ не идентифицированы } \\
\hline & 0,13 & розовое & \\
\hline & 0,08 & желтое & \\
\hline & 0,03 & коричневое & \\
\hline & 0,00 & коричневое & \\
\hline \multirow{4}{*}{23} & 0,20 & розовое & \multirow{4}{*}{ не идентифицированы } \\
\hline & 0,07 & голубое & \\
\hline & 0,02 & синее & \\
\hline & 0,00 & коричневая & \\
\hline \multicolumn{4}{|c|}{ толуол - муравьиная кислота - этилацетат $(5: 1: 4) * *$} \\
\hline \multirow{2}{*}{22} & 0,87 & фиолетовое & \multirow{2}{*}{$\begin{array}{c}\text { ланостерол } \\
\text { не идентифицировано }\end{array}$} \\
\hline & 0,85 & оранжевое & \\
\hline \multirow{2}{*}{23} & 0,83 & фиолетовое & \multirow{2}{*}{$\begin{array}{c}\text { не идентифицировано } \\
\text { инотодиол, траметеноловая кислота }\end{array}$} \\
\hline & 0,76 & оранжевое & \\
\hline
\end{tabular}

Примечание. * отнесение по [20]; ** отнесение по [21].

Таким образом, именно применение колоночной хроматографии позволило разделить липофильные вещества петролейного экстракта меланина чаги. При этом уточнено количественное содержание в экстракте стериновых соединений, которое составляет до $11 \%$ от суммы липофильных веществ, расширен качественный состав липофильных веществ и показано, что до $43 \%$ веществ экстракта представлено углеводородами и восками.

\section{Выводы}

1. Установлено, что применение петролейного эфира для экстракции меланина чаги позволяет выделить до $0,71 \%$ липофильных веществ, что в 12-14 раз меньше по сравнению с их выделением из водного извлечения чаги. 
2. Впервые определено, что липофильные вещества находятся в меланине чаги в связанном состоянии. До $43 \%$ они представлены фракцией углеводородов и восков.

3. Анализ стериновых соединений меланина чаги требует дополнительного разрушения образуемых ими ассоциатов. Их суммарное количество составляет $11 \%$ от содержания в меланине липофильных веществ.

\section{Сиисок литературы}

1. Государственная фармакопея СССР: Вып. 2. Общие методы анализа. Лекарственное растительное сырье. М., 1990. $400 \mathrm{c}$.

2. Сысоева М.А., Кузнецова О.Ю., Гамаюрова В.С. Структурная организация и свойства полифенолов чаги // Вестник Казанского технологического университета. Казань, 2005. № 1. С. 244-250.

3. Сысоева М.А. Высокоактивные антиоксиданты на основе гриба Inonotus obliquus: автореф. дис. ... доктора хим. наук. Казань, 2009. 32 с.

4. Якимов П.А. Общая биологическая и химическая характеристика чаги как исходного сырья для получения лечебных препаратов // Чага и ее лечебное применение при раке IV стадии. Л., 1959. С. 36-48.

5. Рыжова Г.Л., Кравцова С.С., Матасова С.А., Грибель Н.В., Пашинский В.Г., Дычко К.А. Химические и фармакологические свойства сухого экстракта чаги // Химико-фармацевтический журнал. 1997. № 10. С. 44-47.

6. Mazurkiewicz W., Rydel K., Pogocki D., Lemieszek M.K., Langner E., Rzeski W. Separation of an aqueous extract Inonotus obliquus (chaga) // Acta Poloniae Pharmaceutica. 2010. Vol. 67. N 4. Pp. 397-406.

7. Сысоева М.А., Хабибрахманова В.Р., Гамаюрова В.С., Тазеева А.Х. Исследование золя водных извлечений чаги. ХІ. Липиды водного извлечения чаги // Химия растительного сырья. 2008. № 3. С. 119-122.

8. Сысоева М.А., Хабибрахманова В.Р., Гамаюрова В.С., Зайнетдинова Э.Ф. Разделение водных извлечений чаги с использованием этилацетата. III. Состав липидов, отделяемых из водного извлечения чаги этилацетатом // Химия растительного сырья. 2008. № 1. С. 111-114.

9. Хабибрахманова В.Р., Никитина С.А., Сысоева М.А. Исследование золя водных извлечений чаги. XIV. Количественный и качественный состав липидных веществ водного извлечения чаги // Вестник Казанского технологического университета. 2012. Т. 15, №18. С. 217-219.

10. Zheng W. Chemical diversity of biologically active metabolites in the sclerotia of Inonotus obliquus and and submerged culture strategies for up-regulating their production // Appl. Microbiol. Biotechnol. 2010. Vol. 87. Pp. 1237-1254.

11. Chung M.J. Anticancer activity of subfractions containing pure compounds of Chaga mushroom (Inonotus obliquus) extract in human cancer cells and in Balbc/c mice bearing Sarcoma-180 cells // Nutrition research and practice. 2010. Vol. 4. № 3. Pp. 177-182.

12. Kahlos K., Kangas L., Hiltunen R. Antitumor activity of triterpenes in Inonotus obliquus // Planta Medica. 1986. N52. P. 554.

13. Shin Y., Tamai Y., Terazawa M. Triterpenoids, steroids and a new sesquiterpen from Inonotus obliquus (Pers.: Fr.) Bond. et Sing // Int. J. of Medicinal Mushrooms. 2001. Vol. 3. P. 250.

14. Nakata T., Taji S., Yamada T. Structure determination of inonotsuoxides A and B and in vivo anti-tumor promoting activity of inotodiol from the sclerotia of Inonotus obliquus // Bioorganic \& Medicinal Chemistry. 2007. Vol. 15. N1. Pp. 257-264.

15. Сысоева М.А., Кузнецова О.Ю., Гамаюрова В.С., Суханов П.П., Халитов Ф.Г. Исследование золя водных извлечений чаги. II. Изменение изучаемой системы при проведении экстракции различными способами // Вестник Казанского технологического университета. 2003. № 2. С. 172-176.

16. Фармакопейная статья на Бефунгин «ФС 42-3291-96».

17. Заявка на патент №2013116569 (РФ) Способ получения фракции липофильных веществ из чаги / С.А. Никитина, В.Р. Хабибрахманова, М.А Сысоева.

18. Северин С.Е., Соловьева Г.А. Практикум по биохимии. М., 1989. 509 с.

19. Антипов Л.В., Безрядин Н.Н. Физические методы контроля сырья и продуктов в мясной промышленности. СПб., 2006. $200 \mathrm{c.}$

20. Кейтс М. Техника липидологии. М., 1975. 324 с.

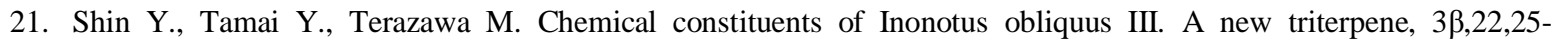
trihydroxy-lanosta-8-ene from sclerotium // Int. J. of Medicinal Mushrooms. 2000. Vol. 2. N 3. Pp. 201-207.

22. Ермаков А.И. Методы биохимического исследования растений. М., 1972. 400 с.

23. Хабибрахманова В.Р. Состав и свойства дисперсной фазы золя водных извлечений чаги: автореф. дис. ... канд. хим. наук. Казань, 2008. 18 с.

24. Никитина С.А., Хабибрахманова В.Р., Сысоева М.А. Липидный состав гриба чаги, водных извлечений и шрота // Химия и технология новых веществ и материалов: тезисы докладов. Сыктывкар, 2012. С. 80.

25. Иоффе Д.В. Стерины как комплексообразователи // Успехи химии. 1986. T. LV, вып. 2. С. 333-349.

26. Гальцова Р.Д. Стеринообразование у дрожжевых организмов. М., 1980. 224 с. 
Nikitina S.A., Habibrahmanova V.R., Sysoeva M.A. STUDY CHAGA MELANIN. I. LIPOPHILIC SUBSTANCES MELANIN CHAGA

Kazan State Technological University, ul. K. Marx, 68, Kazan, 420015 (Russia), e-mail: semicvetik-86@bk.ru

The analysis of quantitative and qualitative composition of lipophilic substances extracted with petroleum ether from the melanin of fungus. Shows the presence of mono-, di- and triglycerides, dialkyl esters of O-glycyl-width, higher fatty acids and aliphatic alcohols, hydrocarbons, waxes, sterols and their esters. First determined that the lipophilic substances are in melanin of fungus in the bound state and their separation was applied column chromatography. Found that up to $43 \%$ of lipophilic substances melanin but fungus-representation and hydrocarbon waxes and up to $11 \%$ - sterols compounds.

Keywords: chaga, water extraction, melanin, lipophilic substances, sterol compounds.

\section{References}

1. Gosudarstvennaja farmakopeja SSSR: Vyp. 2. Obshhie metody analiza. Lekarstvennoe rastitel'noe syr'e. [State Pharmacopoeia of the USSR: Vol. 2. General methods of analysis. Medicinal herbs]. Moscow, 1990, 400 p. (in Russ.).

2. Sysoeva M.A., Kuznecova O.Ju., Gamajurova V.S. Vestnik Kazanskogo tehnologicheskogo universiteta, 2005, no. 1, pp. 244-250. (in Russ.).

3. Sysoeva M.A. Vysokoaktivnye antioksidanty na osnove griba Inonotus obliquus: avtoref. diss. doktora him. nauk. [Highly active anti-oxidants on the basis of the fungus Inonotus obliquus: Doctor of Chemical Sciences diss.]. Kazan', 2009. 32 p. (in Russ.).

4. Jakimov P.A. Chaga i ejo lechebnoe primenenie pri rake IV stadii. [Chaga and its therapeutic use in cancer stage IV]. Leningrad, 1959, pp. 36-48. (in Russ.).

5. Ryzhova G.L., Kravcova S.S., Matasova S.A., Gribel' N.V., Pashinskij V.G., Dychko K.A. Himiko-farmacevticheskij zhurnal, 1997, no. 10, pp. 44-47. (in Russ.).

6. Mazurkiewicz W., Rydel K., Pogocki D., Lemieszek M.K., Langner E., Rzeski W. Acta Poloniae Pharmaceutica, 2010, vol. 67, no. 4, pp. 397-406.

7. Sysoeva M.A., Habibrahmanova V.R., Gamajurova V.S., Tazeeva A.H. Himija rastitel'nogo syr'ja, 2008, no. 3, pp. 119-122. (in Russ.).

8. Sysoeva M.A., Habibrahmanova V.R., Gamajurova V.S., Zajnetdinova Je.F. Himija rastitel'nogo syr'ja, 2008, no. 1, pp. 111-114. (in Russ.).

9. Habibrahmanova V.R., Nikitina S.A., Sysoeva M.A. Vestnik Kazanskogo tehno-logicheskogo universiteta, 2012 , vol. 15, no. 18, pp. 217-219. (in Russ.).

10. Zheng W. Appl. Microbiol. Biotechnol., 2010, vol. 87. pp. 1237-1254.

11. Chung M.J. Nutrition research and practice, 2010, vol. 4, no. 3, pp. 177-182.

12. Kahlos K., Kangas L., Hiltunen R. Planta Medica, 1986, no. 52, p. 554.

13. Shin Y., Tamai Y., Terazawa M. Int. J. of Medicinal Mushrooms, 2001, vol. 3, p. 250.

14. Nakata T., Taji S., Yamada T. Bioorganic \& Medicinal Chemistry, 2007, vol. 15, no. 1, pp. 257-264.

15. Sysoeva M.A., Kuznecova O.Ju., Gamajurova V.S., Suhanov P.P., Halitov F.G. Vestnik Kazanskogo tehnologicheskogo universiteta, 2003, no. 2, pp. 172-176. (in Russ.).

16. Farmakopejnaja stat'ja na Befungin «FS 42-3291-96». (in Russ.).

17. Patent №2013116569 (RU), 2013. (in Russ.).

18. Severin S.E., Solov'eva G.A. Praktikum po biohimii. [Practical work on Biochemistry]. Moscow, 1989, 509 p. (in Russ.).

19. Antipov L.V., Bezrjadin N.N. Fizicheskie metody kontrolja syr'ja i produktov v mjasnoj promyshlennosti. [Physical methods of control of raw materials and products in the meat industry]. St. Petersburg., 2006, 200 p. (in Russ.).

20. Kejts M. Tehnika lipidologii. [Appliances lipidology]. Moscow, 1975, 324 p. (in Russ.).

21. Shin Y., Tamai Y., Terazawa M. Int. J. of Medicinal Mushrooms, 2000, vol. 2, no. 3, pp. 201-207.

22. Ermakov A.I. Metody biohimicheskogo issledovanija rastenij. [Methods of Biochemical Plant Research]. Moscow, 1972, 400 p. (in Russ.).

23. Habibrahmanova V.R. Sostav i svojstva dispersnoj fazy zolja vodnyh izvlechenij chagi: avtoref. dis. ... kand. him. nauk. [Composition and properties of the dispersed phase sol water extracts of fungus: candidate of Chemical Sciences diss.]. Kazan', 2008, 18 p. (in Russ.).

24. Nikitina S.A., Habibrahmanova V.R., Sysoeva M.A. Himija i tehnologija novyh veshhestv i materialov: tezisy dokladov. [Chemistry and technology of new materials: abstracts]. Syktyvkar, 2012, p. 80. (in Russ.).

25. Ioffe D.V. Uspehi himii, 1986, vol. LV, no. 2, pp. 333-349. (in Russ.).

26. Gal'cova R.D. Sterinoobrazovanie u drozhzhevyh organizmov. [Sterinoobrazovanie in yeast organisms]. Moscow, 1980, 224 p. (in Russ.). 